\title{
Factors affecting International Finance Corporation
}

\author{
Hassan Mahmood Aziz ${ }^{1}$, Sarhang Sorguli ${ }^{2}$, Pshdar Abdalla Hamza ${ }^{3}$, Bawan Yassin \\ Sabir ${ }^{4}$, Khowanas Saeed Qader ${ }^{5}$, Bayar Ali Ismeal ${ }^{6}$, Govand Anwar ${ }^{7}$, Bayar Gardi ${ }^{8}$
}

\author{
${ }^{1}$ Department of Accounting and Finance, Faculty of Economics and Administrative Sciences, Cyprus International University, Mersin 10, \\ Haspolat 99040, Cyprus. \\ ${ }^{2}$ Department of Accounting, College of Administration and Financial Sciences, Knowledge University, Kirkuk Road, 44001 Erbil, \\ Kurdistan Region, Iraq. \\ ${ }^{3}$ Department of Business Administration, Kurdistan Technical Institute, Sulaymaniyah, Iraq. \\ ${ }^{4}$ Department of Accounting, College of Administration and Financial Sciences, Knowledge University, Kirkuk Road, 44001 Erbil, \\ Kurdistan Region, Iraq. \\ ${ }^{5}$ Department of accounting and finance, College of Administrations and economics, Lebanese French university, Kurdistan region, Iraq \\ ${ }^{6}$ Department of Accounting, Erbil Technical College, Erbil Polytechnic University. \\ ${ }^{7}$ Department of Business Administration, College of Administration and Financial Sciences, Knowledge University, Kirkuk Road, 44001 \\ Erbil, Kurdistan Region, Iraq. \\ ${ }^{8}$ Department of Accounting, College of Administration and Financial Sciences, Knowledge University, Kirkuk Road, 44001 Erbil, \\ Kurdistan Region, Iraq. Email: bayar.gardi@knu.edu.iq , https://orcid.org/0000-0001-9724-7250
}

Received: 01 May 2021; Received in revised form: 06 Jun 2021; Accepted: 18 Jun 2021

(C2021 The Author(s). Published by TheShillonga. This is an open access article under the CC BY license (https://creativecommons.org/licenses/by/4.0/)

\begin{abstract}
In order to succeed in business, the key is to understand how different processes, practices, rules, regulations, and institutions affect the way the firm is directed, administered, or controlled. The study attempted to investigate factors influencing international finance corporation at small and medium businesses in Erbil. Accordingly, the researchers used six factors for instance; legal factor, environmental factor, political factor, social factor, technical factor, and economic factor to measure influencing international finance. The researchers employed quantitative research method to examine the current study. The questionnaire was distributed randomly among 130 administrative staffs of small and medium businesses. The participants of the present study were 124 participants from different small and medium businesses in Kurdistan region of Iraq. Many different elements, such as currency exchange rates, inflation rates, and the existence of various cultures and languages, determine how profitable international finance can be for companies. This also means that, on the other hand, international finance could be a nightmare if any of these aspects are not handled properly. This also implies that corporations that find themselves involved in financing such deals have no choice but to engage, they must ensure that it is done efficiently. The study demonstrates multiple regression analysis to investigate six research hypotheses, as for first research hypothesis which stated that legal factor influences international finance corporation at small and medium businesses in Erbil, it was found that the value of Beta was .606 with significant level of .000 this indicated that the first research hypothesis was supported, as for second research hypothesis which stated that environmental factor influences international finance corporation at small and medium businesses in Erbil, it was found that the value of Beta was .669 with significant level of .000 this indicated that the second research hypothesis was supported, as for third research hypothesis which stated that political factor influences international finance corporation at small and medium businesses in Erbil, it was found that the value of Beta was .601 with significant level of .002 this indicated that the third research hypothesis was supported, as for fourth research hypothesis which stated that social factor influences international finance corporation at small and medium businesses in Erbil, it was found that the value of Beta was .642 with significant level of .000 this indicated that the fourth research hypothesis was supported, as for fifth research hypothesis which stated that technical factor influences international finance corporation at small and medium businesses in Erbil, it was found that the value of Beta was .642 with significant level of.001 this indicated that the fifth research hypothesis was supported, and as for sixth research hypothesis which stated that technical factor influences international finance
\end{abstract}


corporation at small and medium businesses in Erbil, it was found that the value of Beta was .637 with significant level of .000 this indicated that the sixth research hypothesis was supported.

Keywords-legal factor, social factor, environmental factor, technical factor, political factor, international finance corporation

\section{INTRODUCTION}

Disclosure in accounting is extremely significant to all stakeholders; it brings them the knowledge they need to resolve confusion and helps them to make intelligent financial and economic decisions (Dreher, et al. 2019). firms must produce annual financial reports for external investors, which are often regarded the most critical information sources for outsiders (Sorguli, et al. 2021). In order to succeed in business, the key is to understand how different processes, practices, rules, regulations, and institutions affect the way the firm is directed, administered, or controlled (Sorguli \& Al-Kake, 2020). Not only does the finance corporation comprise the various stakeholders' intricate interconnections, but it is also governed by the stated aims for which it was established. Some rules were established by the Bangladesh Securities and Exchange Commission to help increase the transparency of business reporting (Saleh et al. 2021). The rules that were implemented included: It is critical that the number of the board members of a corporation not be lower than five or higher than twenty. To be effective, all companies should ensure that independent directors are well represented on their board (Sabir, et al. 2021). The board of directors should include directors who are not affiliated with any company. Each director should be independent, and there should be at least one of them. Separation of the chairman and chairwoman of the Finance Corporation is required. It is preferable that the two available jobs be occupied by two people each. The most important factor when staffing global operations is to find and select personnel who can manage operations in various locations around the world (Ismael, et al. 2021). This strategic technique employed by the Finance Corporation is a popular method for coordinating and controlling their wide-ranging worldwide presence (Ismael, et al. 2021).

The notion of financial inclusion began toward the close of the 21 st century, with the understanding that development should not just happen in one part of the world, but rather encompass all parts of the globe (Hamza, et al. 2021). Despite the fact that financial inclusion policies and actions have not historically had a long history, a list of microeconomic and macroeconomic effects in support of the hypothesis that growth in inclusive financial systems is an important component of development progress has been compiled by empirical research (Hameed \& Anwar, 2018). This new digital financial platform-enabled innovation allows more inventive enterprises to enter the market by offering products and services that make both everyday financial transactions and their customers' lives less expensive and more convenient (Gardi, 2021). Payout ratio is calculated by dividing the total dividend paid out to the net profit generated by every stock. We have taken each company's annual net profit and dividends, and computed each one's for every year to ensure that no companies in our results are faced with extremely low or negative net income year to year. Firms are global by their very nature, and the amount of international trade that occurs each year means that financial information produced according to a national accounting system may no longer be relevant to customers whose decisions are made on a worldwide scale (Dreher, et al. 2019). Information that is specific to the home or to a specific region may really be a disadvantage for both businesses and investors (Damit, et al. 2019). When a construction company decides to venture into international markets, it should do so based on a thorough analysis of both the opportunities and threats involved in international business. Such an analysis will also allow the company to discover its strengths and weaknesses relative to international activities. When it comes to construction enterprises, there are various reasons for them to expand their operations into foreign markets (Damit, et al. 2019). To sum up, we can say that sluggish local markets, increasing risk through diversification into new markets, competitive use of resources, and utilizing global prospects are among the primary reasons why investments are not taking place (Aziz, et al. 2021). There is no market in the global economy that is permanently immune to competition from abroad. Regardless of enterprises remaining domestically, they inevitably come into contact with overseas competitors. A critical factor in the global distribution of construction activity is the amount of development that takes place in different parts of the world. Also, because of differing wealth distributions, some areas receive more building activity than others. Performance Standards describe the necessary criteria for evaluating risks and implications for each task and help individuals discover ways to prevent, minimize, and manage these risks and consequences (Anwar, 2017). Additionally, while commercial viability is a central consideration in the overall mission of the Sustainable Development Business Group (SDBG) to promote sustainable development, it is also used to determine which projects SDBG should finance and which financing terms to negotiate on behalf of these projects (Anwar \& Qadir, 2017). One significant result of the expansion of private sector funding in developing 
nations was that state aid and funding became more focused on the private sector. Despite what is frequently said, the formal existence of the Equator Principles, which are commonly referred to as the Equator Principles or the Equator Principles, is merely publicly available in the form of a publicly available document that spells out the normative and business rationale for undertaking environmental risk management (Anwar \& Climis, 2017), and specific operational standards that adopting banks

\section{Conceptual Framework}

commit to using in their project finance activities. Historically, the public sector has been especially active in the infrastructure industry, particularly in developing economies (Ali, et al. 2021), because of the belief that it has strategic importance to the economy, and because the high costs and long timelines typically associated with projects of this nature were considered to be significant deterrents to private investors (Ahmed, et al. 2021).

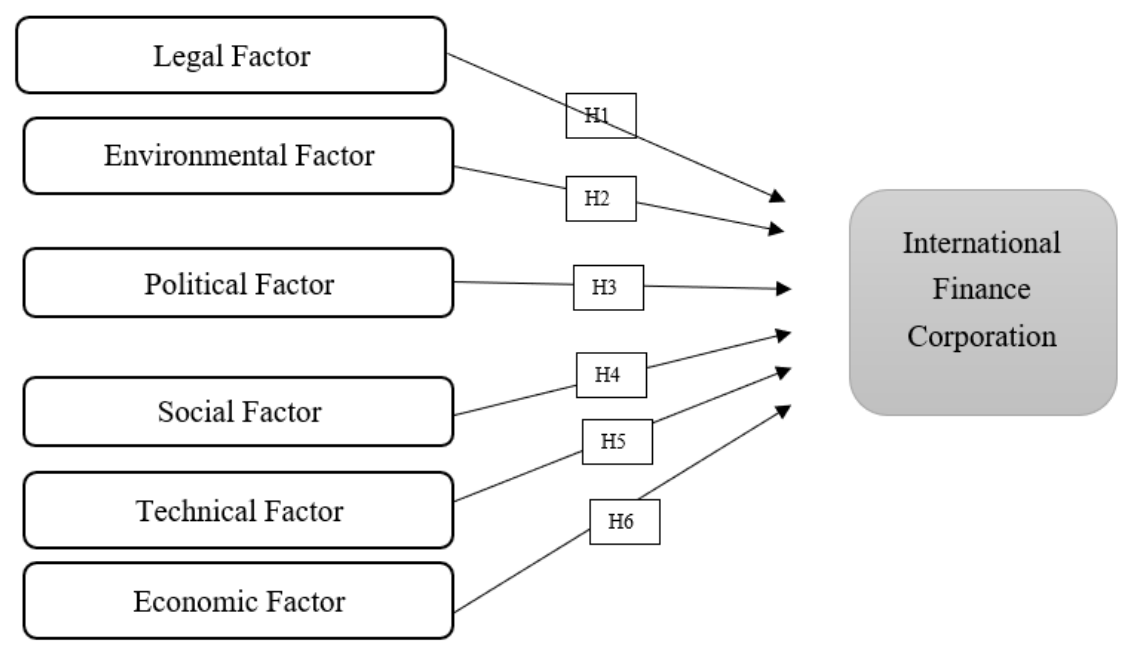

\section{Research Hypotheses:}

Research Hypothesis (1): Legal factor has significant influence on international finance corporation.

Research Hypothesis (2): Environmental factor has significant influence on international finance corporation.

Research Hypothesis (3): Political factor has significant influence on international finance corporation.

Research Hypothesis (4): Social factor has significant influence on international finance corporation.

Research Hypothesis (5): Technical factor has significant influence on international finance corporation.

Research Hypothesis (6): Economic factor has significant influence on international finance corporation.

\section{LITERATURE REVIEW}

\section{International Finance Corporation (IFC)}

IFC is an international financial agency that provides investment, consulting, and asset management services to support private sector development in less developed nations (Abdullah, et al. 2017). A notable amount of research has been conducted on how non-state actors attempt to affect the stock markets and financial corporations. for example, World Bank academics have researched how environmental organizations pressed the institutions to implement environmental and social policies that were thought to be outside of the norm for development in the first place. In many developing nations, finance for private enterprise investment is provided by the IFC, which can give loans and make joint ventures (Abdullah \& Anwar, 2021).

The firm is designed to offer investment and asset management services to the private sector in developing countries. This is done to help bring about the development of private firms and organizations in these countries, which are lacking in the basic infrastructure necessary for doing business (García-Sánchez, et al. 2019). In addition, they promote these enterprises by either obtaining or guaranteeing finance. IFC (International Finance Corporation) offers assist to private businesses in acquiring access to capital markets and other appropriate finance. a nonprofit, private sector development organization linked to the World Bank that finances or encourages investment in member nations regardless of the nationality of the investors the IFC's investment and consulting efforts are meant to aid in reducing poverty and improving the lives of people (Kim, 2018)while maintaining a responsible approach to the environment It is the belief of the organization that sound economic growth is critical to the elimination of poverty; that it is based on the development of entrepreneurship and successful private investment; and that a business-friendly environment is needed for such success to take place and for 
it to make a significant impact on the general public (Kenny, 2020). The International Finance Corporation is an international financial institution that offers investment, consultancy, and asset management services to help promote private sector development in developing nations (García-Sánchez, et al. 2019).

\section{FACTORS AFFECTING INTERNATIONAL FINANCE CORPORATION}

\section{Legal factors:}

Firm operating in a different legal environment might have a significant impact on the legal environment of the country in which it operates (Vanclay, 2017). Citizens in each country are governed by various laws, and multinational commercial firms must adhere to the laws of each country (Smyth \& Vanclay, 2017). Many different rules, such as those that relate to age and disability discrimination, wage rates, employment and environmental regulations, affect businesses' operations (Sorguli, et al. 2020). The international lending institutions' approach to legal and working policies has an impact on the legal culture and practices of businesses (Vanclay, 2020).

\section{Environmental factors:}

Although not a direct cause, external environmental elements like weather, climate change, and temperature influence the business firms' demand patterns for various goods and services (Van der Ploeg \& Vanclay, 2017). Making the environment an external aspect to think about in business has increased the importance of the environment for organizations. The rapid pace of business and industry today, combined with the constant update of the knowledge possessed by accountants (Ascensão, et al. 2018), necessitates the continuous development of the skills and professional competence of accountants, which allows them to deal with more complex financial transactions, as well as the preparation of financial statements and annual reports (Ashrafi, et al. 2018). The overall trend of people shifting towards green products and services has influenced the overall demand pattern for numerous products and services (Gleckman \& Krut, 2017).

\section{Political factors:}

International variables are also influenced by numerous political issues. One of the main reasons why an international business experiences difficulties is because of government policies, tax rates, and policies of the government, as well as political instability in the country where the business is located (Finger, et al. 2018). Because of the close relationship between international business and the legal and political environment in other countries, the effect of other markets on your firm is quite real.
Furthermore, the aforementioned elements are very different from one locale to the next. A lack of political stability in the country undermines the operations of businesses, both large and small (Vanclay \& Hanna, 2019). On top of that, various tax regulations and government activities might negatively impact the growth of business in other countries. Thus, a successful business political climate will have a significant impact on the growth of a commercial enterprise (Ozorhon, et al. 2018).

\section{Social factors:}

social elements such as education, awareness, and general trends and status of the population all effect the consumer behavior, with regards to purchasing various goods and services. a country's value system is affected by the social setting it finds itself in International business, as with any firm, is affected by several elements such as how people feel about riches, the conventions they have, cost structure, labor mobility, and cultural legacy (Kruger \& Eberhard, 2018). The social and cultural factors have an effect on the profession of accounting as a social science and these social and cultural factors interact with one another. Not only is international business influenced by factors within each country (Gardi, 2021), but differences in social environment and culture, such as custom, lifestyle, and value, between countries also directly effects the business (Gardi, 2021). One good example is clients living in one country aren't likely to be interested in the same items and services as consumers living in a foreign country (Brooks \& Oikonomou, 2018).

\section{Technical factors:}

Changes in the technological landscape of the industry have both beneficial and negative effect on the operation of commercial organizations. The fast paced development of technological changes and automated work processes is (Ismael, et al. 2021) helping to increase the overall efficiency of corporate processes (Ali, et al. 2021). One of the main variables to consider when deciding whether or not to expand your business is the influence of technology (Anwar \& Qadir, 2017). The incorporation of accounting technology increases the performance of accounting information systems, and makes them more accurate and flexible for advancements and more valuable to management by providing them with the essential feedback to make sensible decisions (Anwar, 2017). However, technological advancement has also brought with it an increase in the supply of diverse products and services within the business. More advanced technologies are needed in a creative agency or a research laboratory, whereas a legal business or a consulting organization do not need those kind of advanced technologies (Ascensão, et al. 2018). 


\section{Economic factors:}

Factors that influence the economic system in which the firm operates also affect the company's financial wellbeing. Because various economic elements (Brooks \& Oikonomou, 2018), including the inflation rate, interest rate, distribution of income, the number of people employed, and the allocation of government budget, all have an immediate impact on business operations (NDUNGU, 2012). In addition to customers' ability to pay, numerous economic factors such as the purchasing power of customers impact the demand for different goods and services (Hamza, et al. 2021).

\section{METHODOLOGY}

The study was carried out in small and medium businesses in Erbil. The study attempted to investigate factors influencing international finance corporation at small and medium businesses in Erbil. Accordingly, the researchers used six factors for instance; legal factor, environmental factor, political factor, social factor, technical factor, and economic factor to measure influencing international finance. The researchers employed quantitative research method to examine the current study. The questionnaire was distributed randomly among 130 administrative staffs of small and medium businesses. The participants of the present study were 124 participants from different small and medium businesses in Kurdistan region of Iraq.

\section{ANALYSIS AND RESULTS}

Table 1- KMO and Bartlett Sphericity Test of Self-rating Items

\begin{tabular}{|c|c|c|c|c|c|}
\hline \multirow[t]{2}{*}{ Factors } & \multirow{2}{*}{$\begin{array}{l}\mathrm{N} \text { of } \\
\text { items }\end{array}$} & \multirow[t]{2}{*}{$\mathrm{n}$} & \multirow[t]{2}{*}{$\mathrm{KMO}$} & \multicolumn{2}{|c|}{ Bartlett test } \\
\hline & & & & Chi-Square & Sig \\
\hline Legal factor & 10 & 124 & \multirow{7}{*}{.772} & \multirow{7}{*}{1871.3} & \multirow{7}{*}{.000} \\
\hline Environmental Factor & 9 & 124 & & & \\
\hline Political Factor & 11 & 124 & & & \\
\hline Technical Factor & 10 & 124 & & & \\
\hline Economic Factor & 9 & 124 & & & \\
\hline Social Factor & 11 & 124 & & & \\
\hline International Finance Corporation & 10 & 124 & & & \\
\hline
\end{tabular}

As we can see in table (1), the result of KMO for all five independent variables (Legal Factor, Environmental Factor, Political Factor, Social Factor, Technical Factor, and Economic Factor), and International Finance Corporation as dependent variable; is .751 which is higher than .001 this indicates that the sample size used for the current study was more than adequate. Furthermore, the result of Chi-Square is 2155.2 with the significant level .000 .

Table 2: Reliability analysis

\begin{tabular}{|l|c|c|c|}
\hline Factors & N of items & $\mathrm{n}$ & Cronbach's Alpha \\
\hline Legal factor & 10 & 124 & .791 \\
\hline Environmental Factor & 9 & 124 & .737 \\
\hline Political Factor & 11 & 124 & .721 \\
\hline Technical Factor & 10 & 124 & .729 \\
\hline Economic Factor & 9 & 124 & .776 \\
\hline Social Factor & 11 & 124 & .755 \\
\hline International Finance Corporation & 10 & 124 & \\
\hline
\end{tabular}

As seen in table (2), the reliability analysis for 59 items used to measure the influence of six independent variables (Legal Factor, Environmental Factor, Political Factor, Social Factor, Technical Factor, and Economic Factor), and
International Finance Corporation as dependent variable. The above questions were distributed as follow; 10 items for legal factor, 9 items for environmental, 11 items for political, 10 items for technical, 9 items for economic, 10 
items for social factor, and items for 11 items for international finance corporation. The researchers applied reliability analysis to find out the reliability for each factor, the findings revealed as follow: as for legal factor was found the Alpha to be .791 with the sample size of 124 for 10 questions which indicated that all 10 questions used to measure legal factor were reliable for the current study, as for environmental factor was found the Alpha to be .737 with the sample size of 124 for 9 questions which indicated that all 9 questions used to measure environmental factor were reliable for the current study, as for political factor was found the Alpha to be .721 with the sample size of 124 for 11 questions which indicated that all 11 questions used to measure political factor were reliable for the current study, as for technical factor was found the Alpha to be .729 with the sample size of 124 for 10 questions which indicated that all 10 questions used to measure technical factor were reliable for the current study, as for social factor was found the Alpha to be .776 with the sample size of 124 for 11 questions which indicated that all 11 questions used to measure social factor were reliable for the current study, and finally as for international finance corporation was found the Alpha to be .755 with the sample size of 124 for 10 questions which indicated that all 10 questions used to measure international finance corporation were reliable for the current study.

Table 3: Correlation Analysis

\begin{tabular}{|c|c|c|c|c|c|c|c|c|}
\hline \multicolumn{9}{|c|}{ Correlations } \\
\hline & & Legal & Environmental & Political & Technical & Economic & Social & IFC \\
\hline \multirow[t]{3}{*}{ Legal factor } & $\begin{array}{l}\text { Pearson } \\
\text { Correlation }\end{array}$ & 1 & & & & & & \\
\hline & Sig. (2-tailed) & & & & & & & \\
\hline & $\mathrm{N}$ & 124 & & & & & & \\
\hline \multirow[t]{3}{*}{$\begin{array}{l}\text { Environment } \\
\text { al Factor }\end{array}$} & $\begin{array}{l}\text { Pearson } \\
\text { Correlation }\end{array}$ & $.601^{* *}$ & 1 & & & & & \\
\hline & Sig. (2-tailed) & .002 & & & & & & \\
\hline & $\mathrm{N}$ & 124 & 124 & & & & & \\
\hline \multirow[t]{3}{*}{$\begin{array}{l}\text { Political } \\
\text { Factor }\end{array}$} & $\begin{array}{l}\text { Pearson } \\
\text { Correlation }\end{array}$ & $.547^{* *}$ & $.591^{* *}$ & 1 & & & & \\
\hline & Sig. (2-tailed) & .000 & .000 & & & & & \\
\hline & $\mathrm{N}$ & 124 & 124 & 124 & & & & \\
\hline \multirow[t]{3}{*}{$\begin{array}{l}\text { Technical } \\
\text { Factor }\end{array}$} & $\begin{array}{l}\text { Pearson } \\
\text { Correlation }\end{array}$ & $.573^{* *}$ & $.609^{* *}$ & $.618^{* *}$ & 1 & & & \\
\hline & Sig. (2-tailed) & .000 & .001 & .000 & & & & \\
\hline & $\mathrm{N}$ & 124 & 124 & 124 & 124 & & & \\
\hline \multirow[t]{3}{*}{$\begin{array}{l}\text { Economic } \\
\text { Factor }\end{array}$} & $\begin{array}{l}\text { Pearson } \\
\text { Correlation }\end{array}$ & $.587^{* *}$ & $.512^{* *}$ & $.493^{* *}$ & $.482^{* *}$ & 1 & & \\
\hline & Sig. (2-tailed) & .000 & .000 & .000 & .000 & & & \\
\hline & $\mathrm{N}$ & 124 & 124 & 124 & 124 & 124 & & \\
\hline \multirow[t]{3}{*}{$\begin{array}{l}\text { Social } \\
\text { Factor }\end{array}$} & $\begin{array}{l}\text { Pearson } \\
\text { Correlation }\end{array}$ & $.631^{* *}$ & $.667^{* *}$ & $.597^{* *}$ & $.614^{* *}$ & $.632^{* *}$ & 1 & \\
\hline & Sig. (2-tailed) & .000 & .000 & .000 & .000 & .000 & & \\
\hline & $\mathrm{N}$ & 124 & 124 & 124 & 124 & 124 & 124 & \\
\hline \multirow{3}{*}{$\begin{array}{l}\text { International } \\
\text { Finance } \\
\text { Corporation }\end{array}$} & $\begin{array}{l}\text { Pearson } \\
\text { Correlation }\end{array}$ & $.637^{* *}$ & $.648^{* *}$ & $.536^{* *}$ & $.691^{* *}$ & $.644^{* *}$ & $.663^{* *}$ & 1 \\
\hline & Sig. (2-tailed) & .000 & .000 & .000 & .000 & .000 & & \\
\hline & $\mathrm{N}$ & 124 & 124 & 124 & 124 & 124 & 124 & 124 \\
\hline
\end{tabular}


**. Correlation is significant at the 0.01 level (2-tailed).

As it can be seen in table (3), the correlation analysis between (Legal Factor, Environmental Factor, Political Factor, Social Factor, Technical Factor, and Economic Factor), and International Finance Corporation. The finding revealed that the value of Pearson correlation $\left(r=.637^{* *}\right.$, $\mathrm{p}<0.01$ ), between legal factor and International Finance Corporation this indicated that there is positive and strong correlation between legal and International Finance Corporation, the value of Pearson correlation ( $r=$ $.648^{* *} \mathrm{p}<0.01$ ), between environmental factor and International Finance Corporation this indicated that there is positive and strong correlation between environmental factor and International Finance Corporation, the value of Pearson correlation $\left(r=.536^{* *} \mathrm{p}<0.01\right)$, between political factor and International Finance Corporation this indicated that there is positive and strong correlation between political factor and International Finance Corporation, the value of Pearson correlation $\left(\mathrm{r}=.691^{* *} \mathrm{p}<0.01\right)$, between technical factor and International Finance Corporation this indicated that there is positive and strong correlation between technical factor and International Finance Corporation, the value of Pearson correlation $\left(r=.644^{* *} \mathrm{p}<0.01\right)$, between economic factor and International Finance Corporation this indicated that there is positive and strong correlation between economic factor and International Finance Corporation, and the value of Pearson correlation $\left(r=.663^{* *}\right.$ $\mathrm{p}<0.01$ ), between social factor and International Finance Corporation this indicated that there is positive and strong correlation between social factor and International Finance Corporation.

Testing Research Hypotheses

Table 4- Multiple Regression

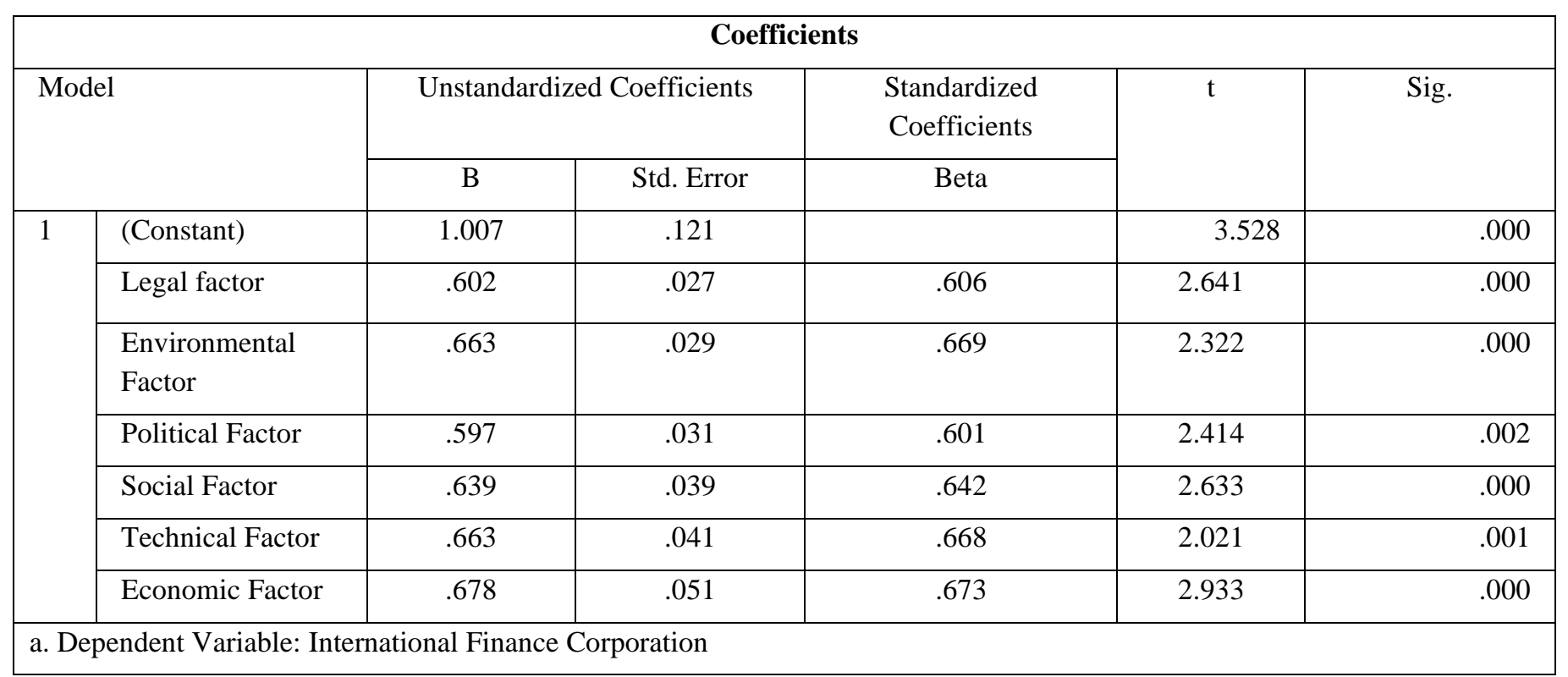

Table (4), demonstrates multiple regression analysis to investigate six research hypotheses, as for first research hypothesis which stated that legal factor influences international finance corporation at small and medium businesses in Erbil, it was found that the value of Beta was .606 with significant level of .000 this indicated that the first research hypothesis was supported, as for second research hypothesis which stated that environmental factor influences international finance corporation at small and medium businesses in Erbil, it was found that the value of Beta was .669 with significant level of .000 this indicated that the second research hypothesis was supported, as for third research hypothesis which stated that political factor influences international finance corporation at small and medium businesses in Erbil, it was found that the value of Beta was .601 with significant level of .002 this indicated that the third research hypothesis was supported, as for fourth research hypothesis which stated that social factor influences international finance corporation at small and medium businesses in Erbil, it was found that the value of Beta was .642 with significant level of .000 this indicated that the fourth research hypothesis was supported, as for fifth research hypothesis which stated that technical factor influences international finance corporation at small and medium businesses in Erbil, it was found that the value of Beta was .642 with significant level of .001 this indicated 
that the fifth research hypothesis was supported, and as for sixth research hypothesis which stated that technical factor influences international finance corporation at small and medium businesses in Erbil, it was found that the value of Beta was .637 with significant level of .000 this indicated that the sixth research hypothesis was supported.

\section{CONCLUSION}

As the years go, this concept is becoming more relevant due to the advent of technology and globalization. Capital management chances go beyond only helping to grow the company and present potential for businesses to do business more effectively. Capital management chances can also benefit clients by boosting competition and promoting the highest standards of customer service. The smaller firms have the biggest challenges since global, massive firms are competing for a share of the market. The quality of products thus has less of a risk of errors. Many different elements, such as currency exchange rates, inflation rates, and the existence of various cultures and languages, determine how profitable international finance can be for companies. This also means that, on the other hand, international finance could be a nightmare if any of these aspects are not handled properly. This also implies that corporations that find themselves involved in financing such deals have no choice but to engage, they must ensure that it is done efficiently. The study demonstrates multiple regression analysis to investigate six research hypotheses, as for first research hypothesis which stated that legal factor influences international finance corporation at small and medium businesses in Erbil, it was found that the value of Beta was .606 with significant level of .000 this indicated that the first research hypothesis was supported, as for second research hypothesis which stated that environmental factor influences international finance corporation at small and medium businesses in Erbil, it was found that the value of Beta was .669 with significant level of .000 this indicated that the second research hypothesis was supported, as for third research hypothesis which stated that political factor influences international finance corporation at small and medium businesses in Erbil, it was found that the value of Beta was .601 with significant level of .002 this indicated that the third research hypothesis was supported, as for fourth research hypothesis which stated that social factor influences international finance corporation at small and medium businesses in Erbil, it was found that the value of Beta was .642 with significant level of .000 this indicated that the fourth research hypothesis was supported, as for fifth research hypothesis which stated that technical factor influences international finance corporation at small and medium businesses in Erbil, it was found that the value of
Beta was .642 with significant level of .001 this indicated that the fifth research hypothesis was supported, and as for sixth research hypothesis which stated that technical factor influences international finance corporation at small and medium businesses in Erbil, it was found that the value of Beta was .637 with significant level of .000 this indicated that the sixth research hypothesis was supported.

\section{REFERENCES}

[1] Dreher, A., Lang, V. F., \& Richert, K. (2019). The political economy of International Finance Corporation lending. Journal of Development Economics, 140, 242-254.

[2] García-Sánchez, I. M., Gómez-Miranda, M. E., David, F., \& Rodríguez-Ariza, L. (2019). Analyst coverage and forecast accuracy when CSR reports improve stakeholder engagement: The Global Reporting Initiative-International Finance Corporation disclosure strategy. Corporate Social Responsibility and Environmental Management, 26(6), 13921406.

[3] Kim, E. (2018). Supreme Court Grants Cert in Jam v. International Finance Corporation. Sup. Ct. Preview, 355.

[4] Kenny, C. (2020). Can the US development finance corporation compete. Center for Global Development. https://www. cgdev. org/sites/default/files/Kenny-CanUSDFC-Compete-Formatted. pdf. Accessed, 30.

[5] García-Sánchez, I. M., Gómez-Miranda, M. E., David, F., \& Rodríguez-Ariza, L. (2019). Board independence and GRIIFC performance standards: The mediating effect of the CSR committee. Journal of Cleaner Production, 225, 554-562.

[6] Vanclay, F. (2017). Project-induced displacement and resettlement: from impoverishment risks to an opportunity for development?. Impact Assessment and Project Appraisal, 35(1), 3-21.

[7] Smyth, E., \& Vanclay, F. (2017). The Social Framework for Projects: a conceptual but practical model to assist in assessing, planning and managing the social impacts of projects. Impact Assessment and Project Appraisal, 35(1), 6580.

[8] Vanclay, F. (2020). Reflections on Social Impact Assessment in the $21 \mathrm{st}$ century. Impact Assessment and Project Appraisal, 38(2), 126-131.

[9] Van der Ploeg, L., \& Vanclay, F. (2017). A human rights based approach to project induced displacement and resettlement. Impact assessment and project appraisal, 35(1), 34-52.

[10] Ashrafi, M., Adams, M., Walker, T. R., \& Magnan, G. (2018). How corporate social responsibility can be integrated into corporate sustainability: a theoretical review of their relationships. International Journal of Sustainable Development \& World Ecology, 25(8), 672-682.

[11] Ascensão, F., Fahrig, L., Clevenger, A. P., Corlett, R. T., Jaeger, J. A., Laurance, W. F., \& Pereira, H. M. (2018). Environmental challenges for the Belt and Road Initiative. Nature Sustainability, 1(5), 206-209.

[12] Gleckman, H., \& Krut, R. (2017). Neither international nor standard: the limits of ISO 14001 as an instrument of global 
corporate environmental management. In ISO 14001 and Beyond (pp. 45-59). Routledge.

[13] Finger, M., Gavious, I., \& Manos, R. (2018). Environmental risk management and financial performance in the banking industry: A cross-country comparison. Journal of International Financial Markets, Institutions and Money, 52, 240-261.

[14] Vanclay, F., \& Hanna, P. (2019). Conceptualizing company response to community protest: principles to achieve a social license to operate. Land, 8(6), 101.

[15] Ozorhon, B., Batmaz, A., \& Caglayan, S. (2018). Generating a framework to facilitate decision making in renewable energy investments. Renewable and Sustainable Energy Reviews, 95, 217-226.

[16] Gardi, B. (2021). Investigating the effects of Financial Accounting Reports on Managerial Decision Making in Small and Medium-sized Enterprises. Turkish Journal of Computer and Mathematics Education (TURCOMAT), 12(10), 21342142.

[17] Ismael, N. B., Sorguli, S., Aziz, H. M., Sabir, B. Y., Hamza, P. A., Gardi, B., \& Al-Kake, F. R. A. (2021). The Impact of COVID-19 on Small and Medium-Sized Enterprises in Iraq. Annals of the Romanian Society for Cell Biology, 24962505.

[18] Gardi, B. (2021). THE EFFECTS OF COMPUTERIZED ACCOUNTING SYSTEM ON AUDITING PROCESS: A CASE STUDY FROM NORTHERN IRAQ. Available at SSRN 3838327.

[19] Damit, D. H. D. A., Harun, A., Martin, D., Othman, B., \& Ahmad, H. (2019). What makes a non-Muslim purchase halal food in a Muslim country? An application of theory of planned behaviour. Management Science Letters, 9(12), 2029-2038.

[20] Kruger, W., \& Eberhard, A. (2018). Renewable energy auctions in sub-Saharan Africa: Comparing the South African, Ugandan, and Zambian Programs. Wiley Interdisciplinary Reviews: Energy and Environment, 7(4), e295.

[21] Brooks, C., \& Oikonomou, I. (2018). The effects of environmental, social and governance disclosures and performance on firm value: A review of the literature in accounting and finance. The British Accounting Review, 50(1), 1-15.

[22] Sorguli, S. H., \& Al-Kake, F. R. A. (2020). The impact of Accounting Information System on Internal Controls in Iraq. Solid State Technology, 63(5), 7024-7036.

[23] Ali, B. J., \& Anwar, G. (2021). Factors Influencing the Citizens' Acceptance of Electronic Government. International Journal of Engineering, Business and Management, 5(1), 4860. https://doi.org/10.22161/ijebm.5.1.5

[24] Saleh, P. F., Ali, B. J., Akoi, S., Najmalddin, B., Ali, R. S., \& Anwar, G. (2021). Factors affecting the Success of Female Entrepreneurs in Kurdistan. International journal of Engineering, Business and Management (IJEBM), 5.

[25] Ali, B. J., Saleh, P. F., Akoi, S., Abdulrahman, A. A., Muhamed, A. S., Noori, H. N., \& Anwar, G. (2021, May). Impact of Service Quality on the Customer Satisfaction: Case study at Online Meeting Platforms. In Ali, BJ, Saleh, Akoi, S., Abdulrahman, AA, Muhamed, AS, Noori, HN, Anwar, G.(2021). Impact of Service Quality on the Customer
Satisfaction: Case study at Online Meeting Platforms. International journal of Engineering, Business and Management (Vol. 5, No. 2, pp. 65-77).

[26] Abdullah, N. N., \& Anwar, G. (2021). An Empirical Analysis of Natural Gas as an Alternative Fuel for Internal Transportation. International Journal of English Literature and Social Sciences, 6(1).

[27] Anwar, K. (2017). Leading Construction Project Teams: The Effectiveness of Transformational Leadership in Dynamic Work Environments in Kurdistan. International Journal of Advanced Engineering, Management and Science, 3(10), 239925.

[28] Anwar, K., \& Qadir, G. H. (2017). A Study of the Relationship between Work Engagement and Job Satisfaction in Private Companies in Kurdistan. International Journal of Advanced Engineering, Management and Science, 3(12), 239944.

[29] Anwar, K., \& Climis, R. (2017). Analyzing the relationship between types of advertisement and customer choice: a study of retailer stores in erbil. The International Journal of Accounting and Business Society, 25(2), 43-52.

[30] Ali, B. J., Saleh, Akoi, S., Abdulrahman, A. A., Muhamed, A. S., Noori, H. N., Anwar, G. (2021). Impact of Service Quality on the Customer Satisfaction: Case study at Online Meeting Platforms. International journal of Engineering, Business and Management, $\quad 5(2), \quad 65-77$. https://dx.doi.org/10.22161/ijebm.5.2.6

[31] Hameed, A. A., \& Anwar, K. (2018). Analyzing the Relationship between Intellectual Capital and Organizational Performance: A Study of Selected Private Banks in Kurdistan. International Journal of Social Sciences \& Educational Studies, 4(4), 39.

[32] Sabir, B. Y., Othman, B .J., Gardi, B., Ismael, N. B., Hamza, P. A., Sorguli, S., Aziz, H. M., Ahmed, S. A., Ali, B. J., Anwar, G. (2021). Administrative Decentralization: The Transfer of Competency from The Ministry of Education to General Directorates. International Journal of Rural Development, Environment and Health Research, 5(3), 1-13. https://doi.org/10.22161/ijreh.5.3.1

[33] Abdullah, M. S., Toycan, M., \& Anwar, K. (2017). The cost readiness of implementing e-learning. CUSTOS E AGRONEGOCIO ON LINE, 13(2), 156-175.

[34] Ali, B. J., Anwar, G., Gardi, B., Othman, B. J., Aziz, H. M., Ahmed, S. A., Hamza, P. A., Ismael, N. B., Sorguli, S., Sabir, B. Y. (2021). Business Communication Strategies: Analysis of Internal Communication Processes. Journal of Humanities and Education Development, 3(3), 16-38. https://doi.org/10.22161/jhed.3.3.4

[35] Aziz, H. M., Othman, B. J., Gardi, B., Ahmed, S. A., Sabir, B. Y., Ismael, N. B., Hamza, P. A., Sorguli, S., Ali, B. J., Anwar, G. (2021). Employee Commitment: The Relationship between Employee Commitment And Job Satisfaction. Journal of Humanities and Education Development, 3(3), 54-66. https://doi.org/10.22161/jhed.3.3.6

[36] Sorguli, S., Gardi, B., Othman, B.J., Aziz, H. M., Ahmed, S. A., Sabir, B. Y., Ismael, N. B., Hamza, P. A., Ali, B. J., Anwar, G. (2021) Innovation: Knowledge Management in the Innovating Industries, $\quad 6(3), \quad 10-23$. https://dx.doi.org/10.22161/eec.63.2 
[37] Hamza, P. A., Othman, B. J., Gardi, B., Sorguli, S., Aziz, H. M., Ahmed, S. A., Sabir, B. Y., Ismael, N. B., Ali, B. J., Anwar, G. (2021). Recruitment and Selection: The Relationship between Recruitment and Selection with Organizational Performance. International Journal of Engineering, Business and Management, 5(3), 1-13. https://doi.org/10.22161/ijebm.5.3.1

[38] Ahmed, S. A., Othman, B. J., Gardi, B., Sabir, B. Y., Ismael, N. B., Hamza, P. A., Sorguli, S., Aziz, H. M., Ali, B. J., Anwar, G. (2021). Students' Attitudes towards Learning English in the Kurdistan region of Iraq. International Journal of English Literature and Social Sciences, 6(3), 072-087. https://doi.org/10.22161/ijels.63.11

[39] Ismael, N. B., Othman, B. J., Gardi, B., Hamza, P. A., Sorguli, S., Aziz, H. M., Ahmed, S. A., Sabir, B. Y., Ali, B. J., Anwar, G. (2021). The Role of Training and Development on Organizational effectiveness. International Journal of Engineering, Business and Management, 5(3), 15-24. https://doi.org/10.22161/ijebm.5.3.3 